\title{
Efficiency of biological control for fall armyworm resistant to the protein Cry1F
}

\author{
C. S. F. Souza $a^{a}$ (D) L. C. P. Silveira ${ }^{a}$ (D), B. H. S. Souza ${ }^{a}$ (D), P. T. Nascimento ${ }^{a}$ (D), \\ N. C. R. Damasceno ${ }^{b}$ (D) and S. M. Mendes ${ }^{* *}$ (ID) \\ aDepartamento de Entomologia, Universidade Federal de Lavras - UFLA, Campus Universitario, CP 3037, CEP 37200-000, \\ Lavras, MG, Brasil

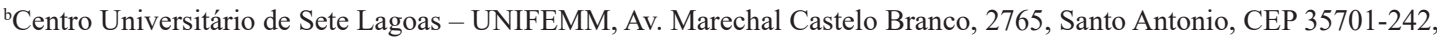 \\ Sete Lagoas, MG, Brasil \\ ${ }^{\mathrm{c}}$ Centro Nacional de Pesquisa de Milho e Sorgo - CNPMS, Rodovia MG 424, Km 45, CP 285, CEP 35701-970, \\ Sete Lagoas, MG, Brasil \\ *e-mail: simone.mendes@embrapa.br
}

Received: June 2, 2019 - Accepted: October 8, 2019 - Distributed: February 28, 2021

(With 1 figure)

\begin{abstract}
Understanding the ecological and toxicological relationship between genetically modified cultivars (GM) and biological control agents is of great importance for discussions related to the compatability of GM cultivars and integrated management strategies for pest resistance. The present study evaluated the search behavior and predatory capacity of Orius insidiosus (Say) (Hemiptera: Anthocoridae) and Doru luteipes (Scudder) (Dermaptera: Forficulidae) on eggs and caterpillars of Spodoptera frugiperda (J. E. Smith) (Lepidoptera: Noctuidae) resistant or not to the protein Cry1F expressed in Bt corn. To determine the search time, a stopwatch was run until the capture of the first prey, predation capacity was evaluated by counting the prey remaining after 24 hours of infestation. The injuries of $S$. frugiperda in genetically modified and conventional corn in the presence and absence of predators was also evaluated. The predators were not able to distinguish between resistant and susceptible prey (eggs or caterpillars), given the predatory behaviour observed. There was no difference in searching time or predatory capacity between the predators for eggs and caterpillars of either resistant or susceptible $S$. frugiperda. In the presence of predators, the injury scores for resistant $S$. frugiperda on the Bt corn plants were lower. It was concluded that $O$. insidiosus and $D$. luteipes did not notice the presence of the protein Cry1F in the prey $S$. frugiperda, which may facilitate the combined use of GM corn and biological control in integrated management programs and for management of pest resistance.
\end{abstract}

Keywords: plant resistance, predatory capacity, tritrophic interaction.

\section{Eficiência do controle biológico da lagarta-do-cartucho resistente à proteína Cry1F}

\begin{abstract}
Resumo
O entendimento de relações ecológicas e toxicológicas envolvendo culturas geneticamente modificadas (GM) e agentes de controle biológico é de grande importância para discussões relativas à compatibilidade de culturas GM com estratégias de manejo integrado e manejo de resistência de pragas. Este trabalho avaliou o comportamento de busca e a capacidade predatória de Orius insidiosus (Say) (Hemiptera: Anthocoridae) e Doru luteipes (Scudder) (Dermaptera: Forficulidae) sobre ovos e lagartas de Spodoptera frugiperda (J. E. Smith) (Lepidoptera: Noctuidae) resistente ou não à proteína Cry1F expressa em milho Bt. Para determinar o tempo de busca foi utilizado um cronômetro que foi disparado até a captura da primeira presa; a capacidade de predação foi avaliada através da contagem das presas remanescentes $24 \mathrm{~h}$ após infestação. Também foram avaliadas as injúrias de $S$. frugiperda em milho transgênico e milho convencional na presença ou ausência dos predadores. Os predadores não foram capazes de distinguir entre presas (ovos ou lagartas) resistentes e suscetíveis, considerando os comportamentos predatórios avaliados. Não houve diferença no tempo de busca e capacidade predatória sobre ovos e lagartas de $S$. frugiperda resistente ou suscetível entre os predadores. $\mathrm{Na}$ presença dos predadores, as notas de injúria de $S$. frugiperda resistente nas plantas de milho Bt foram menores. Conclui-se que $O$. insidiosus e $D$. luteipes não percebem a presença da proteína Cry1F na presa $S$. frugiperda, o que pode contribuir para o uso integrado de milho GM e controle biológico em programas de manejo integrado e manejo de resistência de pragas.
\end{abstract}

Palavras-chave: resistência de plantas, capacidade predatória, interação tritrófica. 


\section{Introduction}

In agricultural cultivation, tropical systems favor the presence of host plants for profligate pests during the greater part of the year during either successive or simultaneous cultivation of diverse cultivars. This availability of host cultivars for pests is known as a green point, and has made the control of insect pests increasingly difficult (Bernardi et al., 2015). Therefore, the use of integrated pest management (IPM), which optimizes the use of different management methods and strategies, has been increasingly recommended in the search for greater sustainability in cultivation systems (Van Lenteren et al., 2018). One of the most widespread pests in tropical cultivation systems and of great importance in the Americas is the fall armyworm Spodoptera frugiperda (J. E. Smith) (Lepidoptera: Noctuidae) (Boregas et al., 2013; Goergen et al., 2016). The fall armyworm is considered the principal pest for corn, reducing the production of grains by up to $34 \%$ (Cruz, 1995; Figueiredo et al., 2006).

The introduction of Bt cultivars into agricultural cultivation has contributed to a change in the economic importance of pest species in crops. Bt corn was first permitted in the 2008/2009 harvest, and since then, the control of pest-lepidoptera has been carried out mainly using transgenic technology, which potentially reduces levels of pesticide use (Storer et al., 2010, 2012). With the use of Bt corn, the combined application of IPM strategies should be encouraged to facilitate the use of the technology for a longer period of time, especially taking into account the evolution of resistance of $S$. frugiperda to Cry proteins expressed in the current events of transgenic corn (Farias et al., 2014; Storer et al., 2010; Huang et al., 2014). The demand for studies into insects resistant to the proteins of Bt plants is growing, both to increase our understanding of the evolution of resistance in insects and to create new strategies for resistance management and IPM (Bernardi et al., 2015).

Natural enemies present a strategic role in pest control (Van Lenteren, 2012). The possibility of combining control strategies, such as insect resistant transgenic plants and bioloigcal control, is desirable due to its low cost, its exploring of other action sites and for being sustainable. Therefore, studies investigating pest and natural enemy interactions in genetically modified cultivars (GM) with insect resistance are necessary (Souza et al., 2018). Ecological interactions between biological control agents and GM cultivars are important for discussions related to the compatibility of transgenic cultivars with different IPM strategies. Though the effect of GM cultivars and biological control agents in the field is difficult to predict, this understanding is fundamental to integrate GM cultivars and biological controls in IPM programs (Lundgren et al., 2009; Schrijver et al., 2016).

The fall armyworm has diverse natural enemies, such as Orius insidiosus (Say) (Hemiptera: Anthocoridae) and Doru luteipes (Scudder) (Dermaptera: Forficulidae). These predators are efficient consumers of eggs and small caterpillars, acting as important biological control agents (Albajes et al., 2003; Silveira et al., 2004; Cruz et al., 1995; Figueiredo et al., 2006; Cruz, 2007; Pasini et al., 2007; Araújo et al., 2011; Mendes et al., 2012b; Moscardini et al., 2013; Wong and Frank, 2013). Predation is one of the most important ecological interactions for the stability of agroecosystems, given that predators are more generalist than parasitoids. The fact that many of them are omnivorous means that they are able to establish themselves in the area for longer (Schrijver et al., 2016). In Brazil, O. insidiosus is the most abundant species of the Orius genus, and presents the greatest potential for use in biological control programs (Mendes et al., 2012a). D. luteipes is a predatory species from tropical climates of importance in Brazil, being relevant in the control of fall armyworm in corn (Reis et al., 1988; Cruz, 1995).

Natural enemies can slow the evolution of resistance to Bt proteins in pests (Liu et al., 2014). However, the majority of studies regarding tritrophic interactions with prey exposed to Bt proteins and effects on their natural enemies, are realized through the evaluation of biological variables (Romeis et al., 2013). The responses to these interactions can raise important questions related to behavioral changes of non-target organisms for GM plants. Behavioral studies investigating searching times and predation capacities can assist in the implementation of IPM strategies that involve the simultaneous use of Bt cultivars and biological controls. Protocols established by Romeis et al. (2013) and Schrijver et al. (2016) include a list of characteristics to be evaluated in beneficial insects such as non-target organisms, especially natural enemies. Mendes et al. (2012a) considers that predation behaviour can also be altered as a result of the use of Bt plants, and proposes new methodologies that take into consideration the evaluation of behavioural parameters of predation.

Recently, Souza et al. (2018) showed the transferance of Cry1F protein of transgenic corn to the first generation of $S$. frugiperda (second trophic level), an outcome that could be influenced through interaction with the third trophic level. The results of this study can provide help when using these biological control agents in conjunction with $\mathrm{Bt}$ corn in the reduction of injuries caused by the fall armyworm and, in this manner, aid in the management of the pest. Therefore, the objective of the present study was to evaluate the searching behaviour and predatory capacity of $O$. insidiosus and $D$. luteipes on the eggs and caterpillars of $S$. frugiperda resistant to the Cry $1 \mathrm{~F}$ protein expressed in Bt corn.

\section{Material and Methods}

Insect rearing and performance of the bio-assays were conducted in the Ecotoxicology and Insect Management laboratories of Embrapa Corn and Sorghum, in Sete Lagoas, MG. The hybrid used was Herculex ${ }^{\circledR}$ which expresses the protein Cry1F (event TC1507) and its conventional isogenic version, as the control. 


\subsection{Rearing of insects}

The rearing of $S$. frugiperda was performed according to the methodology described by Cruz (2000), in a room acclimatized at $25 \pm 2{ }^{\circ} \mathrm{C}, 12$ hour photophase and $60 \pm 10 \%$ of relative humidity. Neonate caterpillars were placed in $50 \mathrm{~mL}$ plastic cups containing artificial diet, following Parra (1996). After five days, the caterpillars were separated in $50 \mathrm{~mL}$ cups containing artificial diet and sealed with acrylic lids until the emergence of adults. Neonate $S$. frugiperda caterpillars selected in terms of resistance to the protein Cry $1 \mathrm{~F}$ were maintained according to Leite et al. (2016).

The rearing of $O$. insidiosus was carried out according to the methodology described by Bueno (2000) and Mendes and Bueno (2001). The pirate bugs were raised in Petri dishes (20 cm diameter) containing a nesting area (paper towel), water source (moistened cotton wool) and food (Ephestia kuehniella (Zeller) (Lepidoptera: Pyralidae) eggs offered ad libitum). The rearing of $D$. luteipes was realized according to Cruz (2000). The earwigs were kept in PVC cages during the adult phase, on corn leaves (nesting area), water (moistened cotton) and food (artificial diet based on cat food $(35 \%)$, wheat bran $(27 \%)$, beer yeast (23\%), milk powder (14\%), Nipagin (5\%), and ascorbic acid $(5 \%)$. The nymphs were maintained in Petri dishes (20 cm diameter) including a nesting area (folded sulphite paper). The rearing were kept in an aclimatized room at $25 \pm 2{ }^{\circ} \mathrm{C}$, with 12 hour photophase and $60 \pm 10 \%$ relative humidity.

\subsection{Searching time and predation capacity}

Searching time and predation capacity were evaluated with $1^{\text {st }}, 3^{\text {rd }}$ and $4^{\text {th }}$ instar $D$. luteipes nymphs and $1^{\text {st }}, 3^{\text {rd }}$ and $5^{\text {th }}$ instar $O$. insidiosus nymphs, fed with $S$. frugiperda eggs obtained from a population resistant to the Cry1F protein or from a susceptible population, such as the control. The evaluations of searching time and predation capcity were also realized with $3^{\text {rd }}$ and $4^{\text {th }}$ instar $D$. luteipes nymphs and $3^{\text {rd }}$ and $5^{\text {th }}$ instar $O$. insidiosus nymphs fed with neonate $S$. frugiperda caterpillars from a population resistant or susceptible to the protein Cry1F, totaling 20 treatments with 22 repetitions.

Searching time was evaluated using a stopwatch. when the predator was placed in the dish, the stopwatch was started until the predator caught its first prey, at which point the watch was stopped and the time recorded. After 24 hours, the prey consumed within this time interval were counted to determine predation capacity. The number of prey provided was established according to the predator and the corresponding instar, based on a pre-test. The eggs were separated from the egg masses for counting, using a fine bristled brush. A pre-test was realized in order that the number of prey was offered ad libitum. For the bio-assay with caterpillars, a piece of non-Bt corn leaf (conventional isogenic TC1507) was offered, in addition to moistened cotton wool to guarantee the survival of the unconsumed caterpillars.

A piece of moistened cotton wool $(\sim 2.0 \times 1.0 \mathrm{~cm})$ was placed in the dishes to avoid drying out, following which, the dishes were sealed with plastic wrap. $24 \mathrm{~h}$ prior to the experiment, the predators were maintained without food, having access only to water (moistened cotton wool). Unconsumed eggs were counted after $24 \mathrm{~h}$ to determine predation capacity. For the control, dishes containing only caterpillars, a section of corn leaf and moistened cotton wool were used. After $24 \mathrm{~h}$, the evaluation of caterpillar survival was carried out.

\subsection{Injury caused by $S$. frugiperda resistant to the protein CrylF in Bt corn in the presence and absence of predators}

The bioassay was installed in a greenhouse $\left(25 \pm 5^{\circ} \mathrm{C}\right.$, $70 \pm 15 \%$ UR, natural light) on May 30th, 2016 in Embrapa Corn and Sorghum. For the experiment, Herculex ${ }^{\circledR}$ corn was used that expresses the protein Cry1F (event TC1507) and its conventional isogenic version, as a control. For Bt corn, the following combinations were applied: 1) caterpillars $+O$. insidiosus; 2) caterpillars $+D$. luteipes; 3 ) caterpillars $+O$. insidiosus $+D$. luteipes; 4) only caterpillars; and 5) conventional corn with only caterpillars. In the treatments with Bt corn, caterpillars resistant to the protein Cry $1 \mathrm{~F}$ were used, and susceptible caterpillars were used in the treatment with conventional corn, with the aim of evaluating the interaction of resistant and susceptible populations, in a total of five treatments.

For each treatment, 12 pots $(20 \mathrm{~L})$ containing soil fertilized with $50 \mathrm{~g}$ of NPK 08-28-16 and $0.3 \%$ of $\mathrm{Zn}$ were used. Each pot was considered a repetition, with three corn plants in each. When the plants reached the V6 stage (Ritchie et al., 1986), they were infested with five neonate caterpillars $(<24 \mathrm{~h})$ per plant with the help of a fine brush. The containers were covered with voile fabric cages, and after $24 \mathrm{~h}$, the $3^{\text {rd }}$ instar predators were freed.

Evaluations were performed by injury score, according to the scale proposed by Carvalho (1970), performed 7, 14 and 21 days after infestation by the caterpillars. The injuries varied from 0 (zero) to (five), where: $0=$ plants without injury; $1=$ plants with shaved leaves; 2 = plants with perforated leaves; $3=$ plants with lesions on the leaves and stalks; $4=$ plants with nearly destroyed stalks; and $5=$ plants with many leaves and stalks totally destroyed. On the $21^{\text {st }}$ day after infestation, the number of caterpillars remaining per container, survival and the body biomass of the caterpillars were also evaluated. The evaluation of the biomass was performed with the help of a precision analytic scale $(0.0001 \mathrm{~g})$ (brand: Mettler Toledo, model: ML204, manufactured in 2014 in Switzerland).

\subsection{Statistical analysis}

Searching time and predatory capacity assays were performed with an entirely random design in a factorial scheme $(3 \times 2)$ with the type of prey $($ egg or caterpillar - resistant or susceptible) and the stage of development of the predator being considered as the two factors. The data were submitted to factorial analysis of variance to determine the main effects of each factor, as 
well as the effects of their interaction. When significant, the averages were compared by Tukey test at $5 \%$ probability. In the greenhouse assay, an entirely random design was adopted. For the survival and biomass variables for the caterpillars, the data were analyzed using analysis of variance and the averages compared by Tukey test, at 5\% probability. The injury scores were analyzed by confidence interval at $5 \%$ probability. The analyzes were performed in the Statistica 7.0 Statistical Program.

\section{Results}

\subsection{Searching time and predation capacity}

There was no significant difference for the searching time of $O$. insidiosus for eggs of susceptible or resistant $S$. frugiperda $(F=0.34 ; d f=2.12 ; P=0.5628)$ or between the different instars of the predator, while the instar $\mathrm{x}$ prey interaction did not show significance $(F=0.524$; $d f=2.12 ; P=0.5931)$. For the predation capacity for $O$. Insidiosus, there was also no significant difference $(F=0.10 ; d f=2.12 ; P=0.7515)$ between the types of prey. However, there was a difference between the instars $(F=19.18 ; d f=2.12 ; P=0.0000) ; 1^{\text {st }}$ instar $O$. insidiosus nymphs preyed on the least number of eggs in $24 \mathrm{~h}$ in comparison with the $3^{\text {rd }}$ and $5^{\text {th }}$ instar nymphs, while the prey $\mathrm{x}$ instar interaction was not significant $(F=1.97$; $d f=2.12 ; P=0.1426$ ) (Table 1$)$.

A significant difference $(F=12.85 ; d f=1.84 ; P=0.0005)$ for the searching time of $O$. insidiosus for $S$. frugiperda neonate caterpillars was only observed for the nymph instars. $3^{\text {rd }}$ instar nymphs presented significantly longer searching times than $5^{\text {th }}$ instar nymphs. However, there was no significant difference in relation to the type of prey (resistant or susceptible) $(F=0.20 ; d f=1.84 ; P=0.6505)$, nor in relation to the instar $\mathrm{x}$ prey interaction $(F=0.64$; $d f=1.84 ; P=0.4244)$. For the predation capacity for $O$. insidiosus for $S$. frugiperda neonate caterpillars, no significant difference was observed between the prey $(F=2.00 ; d f=1.84 ; P=0.1603)$, instars $(F=0.03$; $d f=1.84 ; P=0.8573)$ or for the instar x prey interaction $(F=0.41 ; d f=1.84 ; P=0.5214)$ (Table 1$)$.
There was no significant difference for searching time for $D$. luteipes for either prey, eggs $(F=103 ; d f=1.12$; $P=0.3118)$ or caterpillars $(F=0.16 ; d f=1.84 ; P=0.6881)$, neither resistant or susceptible. However, there was a difference between the instars for searching time with eggs $(F=4.35 ; d f=2.12 ; P=0.0148)$, where the first instar took longer to capture its first prey in relation to the $3^{\text {rd }}$ and $4^{\text {th }}$ instars. In relation to the prey when they were caterpillars, there was no significant difference in the searching time between the $3^{\text {rd }}$ and $4^{\text {th }}$ instars $(F=1.02$; $d f=1.84 ; P=0.3141)$.

The instar $\mathrm{x}$ prey interaction also presented no significance in relation to the time for eggs $(F=0.06$; $d f=1.12 ; P=0.9336)$ or caterpillars $(F=4.23 ; d f=1.84$; $P=0.0526)$. For the $D$. Luteipes predation capacity, there was no significant difference for either eggs $(F=0.51$; $d f=1.12 ; P=0.4761)$ and caterpillars $(F=3.44 ; d f=1.84$; $P=0.0672$ ) between the resistant and susceptible prey. However, there was a significant difference between the instars in terms of the predation capacity for eggs $(F=154.07$; $d f=1.84 ; P=0.0000)$ and caterpillars $(F=5.66 ; d f=1.84$; $P=0.0195)$. There was a lower predation capacity for eggs and caterpillars by $D$. luteipes in the first instars in comparison with the last instar (Table 2). The instar $\mathrm{x}$ prey interaction in relation to predation was also not significant for either eggs $(F=2.69 ; d f=2.12 ; P=0.0714)$ or caterpillars $(F=1.04 ; d f=1.84 ; P=0.3116)$.

\subsection{Injury caused by $S$. frugiperda resistant to the protein CrylF in Bt corn in the presence and absence of predators}

There was a significant difference between the treatments in the assay to evaluate injury of $S$. frugiperda (Figure 1). The injury scores in Bt corn with only caterpillars resistant to the protein Cry1F and in conventional corn with susceptible caterpillars, were significantly greater than in the treatments with Bt corn, caterpillars and predators in the three time intervals. In the Bt corn treatment with only resistant caterpillars, there was an increase in the injury scores from the first to the last evaluation, not differing from the conventional corn treatment with susceptible caterpillars. When only $O$. insidiosus was present in the

Table 1. Searching time and predation capacity of Orius insidiosus (Say) (Hemiptera: Anthocoridae) of eggs and caterpillars of Spodoptera frugiperda (J. E. Smith) (Lepidoptera: Noctuidae) resistant and susceptible to the protein Cry1F.

\begin{tabular}{|c|c|c|c|c|}
\hline \multirow{3}{*}{ Instar } & \multicolumn{2}{|c|}{ Time (seconds) } & \multicolumn{2}{|c|}{ Predation (prey consumed) } \\
\hline & \multicolumn{4}{|c|}{ Eggs } \\
\hline & Resistant $^{\text {ns }}$ & Susceptible $^{\text {ns }}$ & Resistant* & Susceptible* \\
\hline $1^{\text {st }}$ & $784.82 \pm 178.23$ & $735.00 \pm 174.99$ & $1.50 \pm 0.13 \mathrm{~b}$ & $1.55 \pm 0.11 b$ \\
\hline $3^{\text {rd }}$ & $398.00 \pm 106.14$ & $602.41 \pm 212.92$ & $2.32 \pm 0.20 \mathrm{a}$ & $2.64 \pm 0.27 \mathrm{a}$ \\
\hline \multirow[t]{3}{*}{$5^{\text {th }}$} & $957.55 \pm 210.42$ & $551.77 \pm 132.37$ & $3.09 \pm 0.27 \mathrm{a}$ & $2.95 \pm 0.28 \mathrm{a}$ \\
\hline & \multicolumn{4}{|c|}{ Caterpillars } \\
\hline & Resistant* & Susceptible* & Resistant $^{\text {ns }}$ & Susceptible $^{\text {ns }}$ \\
\hline $3^{\text {rd }}$ & $703.95 \pm 150.77 \mathrm{a}$ & $555.95 \pm 142.54 \mathrm{a}$ & $3.50 \pm 0.22$ & $3.73 \pm 0.20$ \\
\hline $5^{\text {th }}$ & $258.55 \pm 102.79 \mathrm{~b}$ & $190.36 \pm 34.89 b$ & $3.91 \pm 0.47$ & $4.64 \pm 0.39$ \\
\hline
\end{tabular}

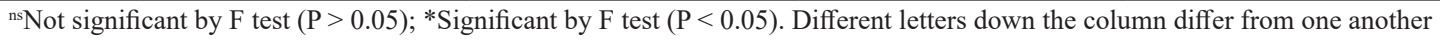
according to the Tukey test $(\mathrm{P}<0.05)$. 
plants, the highest score presented was 21 days after infestation. In the treatment in which only $D$. luteipes was present, the injury score dropped from the first to the last evaluation. Finally, when both predators were introduced

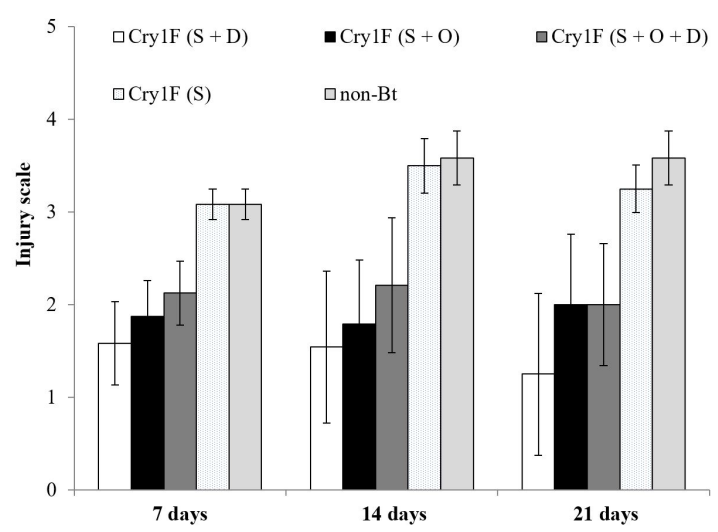

Figure 1. Injury scale (0-5) for Spodoptera frugiperda (J. E. Smith) (Lepidoptera: Noctuidae) in corn plants at 7,14 and 21 days after infestation by recently hatched caterpillars in the presence or absence of predators. Cry1F $=$ Bt corn TC1507; S = S. frugiperda (J. E. Smith) (Lepidoptera: Noctuidae); O = Orius insidiosus (Say) (Hemiptera: Anthocoridae); and D = Doru luteipes (Scudder) (Dermaptera: Forficulidae). Intervals between adjacent bars do not differ from one another by the confidence interval $(\mathrm{P}>0.05)$. onto the plants, the injury score presented a small increase from 7 to 14 days and dropped at 21 days.

In terms of the survival of $S$. frugiperda caterpillars 21 days after infestation (Table 3 ), there was a significant difference $(F=4.774 ; d f=4.44 P=0.0028)$ between the treatments. For the Bt corn treatment with resistant caterpillars in the presence of one of the species or both predators, larval survival was on average 2.4 times less in relation to the treatments with conventional corn with suceptible caterpillars and Bt corn with resistant caterpillars. There was no significant difference $(F=1.932 ; P=$ 0.1183 ) between the treatments for the body biomass of the caterpillars, which was on average $264.76 \mathrm{mg}$ after 21 days (Table 3 ).

\section{Discussion}

The results showed a good predation capacity for both $S$. frugiperda predators, mainly in the more advanced instars. Given that the eggs did not present a defense reaction against predation by the insects, we can infer that the only difficulty in the process of searching and capture of the prey is in detection. In more advanced instars of both predators, a greater predation capacity was observed for eggs. This was expected, given that the older the insect, the greater its food requirements (Bortoli et al., 2016; Cruz et al., 1995; Mendes and Bueno, 2001; Mendes et al., 2003; Oliveira et al., 2008; Reis et al., 1988).

When the prey were neonate $S$. frugiperda caterpillars, the searching time of nymphs of the different $O$. insidiosus

Table 2. Searching time and predation capacity of Doru luteipes (Scudder) (Dermaptera: Forficulidae) for eggs and caterpillars of Spodoptera frugiperda (J. E. Smith) (Lepidoptera: Noctuidae), resistant and susceptible to the protein Cry1F.

\begin{tabular}{|c|c|c|c|c|}
\hline \multirow{3}{*}{ Instar } & \multicolumn{2}{|c|}{ Time (seconds) } & \multicolumn{2}{|c|}{ Predation (prey consumed) } \\
\hline & \multicolumn{4}{|c|}{ Eggs } \\
\hline & Resistant* & Susceptible* & Resistant* & Susceptible* \\
\hline $1^{\text {st }}$ & $114.00 \pm 38.58 \mathrm{a}$ & $97.64 \pm 50.42 \mathrm{a}$ & $16.09 \pm 0.96 \mathrm{c}$ & $17.86 \pm 1.00 \mathrm{c}$ \\
\hline $3^{\text {rd }}$ & $65.55 \pm 14.84 b$ & $58.68 \pm 17.34 b$ & $28.68 \pm 1.60 \mathrm{~b}$ & $24.64 \pm 1.70 b$ \\
\hline \multirow[t]{3}{*}{$4^{\text {th }}$} & $32.86 \pm 6.66 \mathrm{~b}$ & $30.82 \pm 11.17 \mathrm{~b}$ & $70.32 \pm 2.60 \mathrm{a}$ & $67.68 \pm 2.69 \mathrm{a}$ \\
\hline & \multicolumn{4}{|c|}{ Caterpillars } \\
\hline & Resistant $^{\text {ns }}$ & Susceptible $^{\text {ns }}$ & Resistant* & Susceptible* \\
\hline $3^{\text {rd }}$ & $30.68 \pm 12.61$ & $213.64 \pm 84.55$ & $12.18 \pm 0.55 \mathrm{~b}$ & $10.18 \pm 0.69 b$ \\
\hline $4^{\text {th }}$ & $91.55 \pm 46.88$ & $86.41 \pm 37.41$ & $41.05 \pm 2.36 \mathrm{a}$ & $43.09 \pm 1.42 \mathrm{a}$ \\
\hline
\end{tabular}

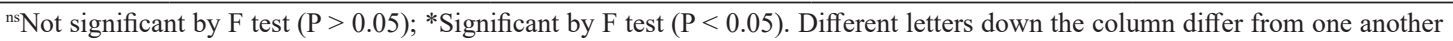
according to the Tukey test $(\mathrm{P}<0.05)$.

Table 3. Survival (\%) and biomass (mg) of Spodoptera frugiperda (J. E. Smith) (Lepidoptera: Noctuidae) after 21 days in the presence or absence of predators.

\begin{tabular}{ccc}
\hline Treatments & Survival $\mathbf{( \% )}$ & Biomass $\left._{(\mathbf{m g})}\right)^{\mathbf{n s}}$ \\
\hline Cry 1F (S + D) & $6.11 \pm 3.01 \mathrm{~b}$ & $172.60 \pm 49.30$ \\
Cry 1F (S + O) & $12.78 \pm 4.38 \mathrm{ab}$ & $239.43 \pm 26.97$ \\
Cry 1F (S + O + D) & $8.33 \pm 2.34 \mathrm{ab}$ & $273.56 \pm 30.75$ \\
Cry 1F (S) & $21.11 \pm 3.05 \mathrm{a}$ & $282.56 \pm 20.60$ \\
Non-Bt (S) & $22.00 \pm 3.56 \mathrm{a}$ & $355.65 \pm 36.91$ \\
\hline
\end{tabular}

${ }^{n s}$ Not significant by $\mathrm{F}$ test $(\mathrm{P}>0.05)$. *Significant by $\mathrm{F}$ test $(\mathrm{P}<0.05)$. Different letters down the column differ from one another according to the Tukey test $(\mathrm{P}<0.05)$. Cry $1 \mathrm{~F}=\mathrm{Bt}$ corn $\mathrm{TC} 1507 ; \mathrm{S}=\mathrm{S}$. frugiperda; $\mathrm{O}=$ Orius insidiosus (Say) (Hemiptera: Anthocoridae); and D = Doru luteipes (Scudder) (Dermaptera: Forficulidae). 
instars was variable. This can be explained by the fact that the caterpillars presented a defense reaction to predation behaviour. This difficulty is greater for the younger instars, given that $O$. insidiosus is a small insect $(\sim 2.5 \mathrm{~mm}$ in the adult phase), and nearly the same size as its prey. In the case of $5^{\text {th }}$ instar nymphs, this problem was less evident. This behaviour of $O$. insidiosus was also observed by Mendes et al. (2012b) for caterpillars that fed on corn with the protein CrylAb. The authors attributed greater ease of predation of caterpillars that fed on Bt corn, given that this event is considered to be low dose (Sousa et al., 2016) and leads to sublethal toxic effects, leaving the caterpillars more susceptible to predation. However, in the research by Mendes et al. (2012b), neither predator differed in terms of the prey fed or not with Bt corn (CrylAb), since the caterpillars presented similar development. In the present study, given that the $S$. frugiperda caterpillars were from a population resistant to the protein Cry1F, they did not present a reduction in development, sublethal effects or a difference in the reaction to predation in relation to the susceptible population. This highlights the need to perform biosecurity studies for the approvement of GM cultivars (guidlines $n^{\circ} 6$ of 2008 and $n^{\circ} 8$ of 2009, CTNBio, 2009).

The majority of studies found in the literature (Romeis et al., 2006, 2008; Mendes et al., 2012a; Leite et al., 2014; Tian et al., 2015; Paula et al., 2016) generally present results different to those in this study, since they evaluate the direct and indirect effects of Bt cultures on non-target organisms using susceptible prey and that feed on the Bt plant moments before exposure to the predators. In the present study, the prey were obtained from genitors resistant to the protein Cry1F. Therefore, they did not need to feed on the toxin in subdoses, and the predators were not fed with prey of low nutritional value due to the susceptibility to the protein (Naranjo, 2009; Romeis et al., 2006; Lundgren et al., 2009).

This is a method suggested to sidestep the effects of the nutritional quality of the host, which means that the results obtained are close to the real conditions in the field (Romeis et al., 2011; Shelton et al., 2016). For example, the predator Chrysoperla carnea (Stephens) (Neuroptera: Chrysopidae) was negatively affected when it fed on the susceptible caterpillars of Helicoverpa armigera (Hübner) (Lepidoptera: Noctuidae) reared in Bt cotton; however, they were not affected when they fed on caterpillars resistant to the protein Cry1 Ac of Bt cotton. Therefore, susceptibility to the protein possibly generated prey of low nutritional value, which may have led to alterations in the biological parameters of the predator (Lawo et al., 2010).

The predator $D$. luteipes showed a greater ability in relation to time, for predation throughout the developmental phases of the prey, both eggs and caterpillars. This characteristic corresponds to an advantage of the predator in interaction with prey. Leite et al. (2014) in a similar experiment, for the searching time of the predator, Podisus nigrispinus (Dallas) (Hemiptera: Pentatomidae), for S. frugiperda caterpillars between three and seven days of age. In this case, the more advanced the instar of the predator, the longer the searching time, which could mean that the predatory behaviour could differ between the predators and between the prey of different sizes. Therefore, these results underline the resolution of the CTNBio ( $n^{\circ} 6$ of 2008 and $n^{\circ} 8$ of 2009) in which the evaluation of the risk for non-target organisms should be realized on a case by case basis (CTNBio, 2008).

The predatory capacity of $D$. luteipes for recently hatched S. frugiperda caterpillars was influenced by the stage of development of the predator, but not by the resistance status of the pest to the protein Cry1F. The number of caterpillars consumed was greater in $5^{\text {th }}$ instar nymphs, that is, there was an increase in the need for food according to the development of the predator. The earwig $D$. luteipes also presented an increasing consumption of eggs of Helicoverpa zea (Boddie) (Lepidoptera: Noctuidae) as a function of nymphal instars. Cruz et al. (1995) evaluated the daily consumption of $H$. zea eggs in every nymphal phase of D. luteipes, with 45.3 eggs being consumed on average per day in the $4^{\text {th }}$ instar. The results of the present study indicate that on average, $5^{\text {th }}$ instar D. luteipes nymphs consumed 70 eggs and 43 recently hatched $S$. frugiperda caterpillars in $24 \mathrm{~h}$. These findings show the efficiency of the earwig in consuming eggs of two of the most important corn pests. Mendes et al. (2012b) observed in a feeding preference test that $D$. luteipes opted to remain longer where there were caterpillars that had not fed on Bt corn (CylAb and Cry1F), but the searching time of first instar nymphs was longer for these caterpillars. The authors suggested that, when the caterpillars feed on Bt corn, they become more susceptible to attack by the predator, mainly in the younger stages, where they have more difficulty caputring prey.

In the present study, $O$. insidiosus presented slight, although, greater difficulty in capturing caterpillars when they were in the $3^{\text {rd }}$ instar in comparison with the $5^{\text {th }}$. However, the predator was not influenced by whether the prey was resistant or susceptible to the Bt protein, given that caterpillars of both populations presented similar behaviour for reaction to predation and development. This shows that the agility of predation increases with the growth of this species of predator. However, both the $O$. insidiosus instars evaluated consumed a larger number of caterpillars in comparison to eggs, even if in the $3^{\text {rd }}$ instar, the nymphs showed greater difficulty in capturing the caterpillars, indicating a preference for this developmental stage of the prey (Mendes et al., 2002; Butler and O'Neil, 2006; Chow et al., 2010; Yoo and O'Neil, 2009; Dogramaci et al., 2011; Perdikis et al., 2011; Wong and Frank 2013). Therefore, it is evident that foraging behaviour and predatory capacity can vary according to the predator and its prey in GM cultivars, and should be considered more specifically.

Experiments with Coleomegilla maculata (DeGeer) (Coleoptera: Coccinellidae) feeding on Trichoplusia ni (Hübner) (Lepidoptera: Noctuidae) resistant to the proteins Cry2Ab and Cry1Ac, S. frugiperda resistant to the protein Cry1F, and Plutella xylostella (Linnaeus) (Lepidoptera: Plutellidae) resistant to the protein Cryl Ac did not show adverse effects in the biological variables for this earwig. 
Additionally, there was no difference in the food choice of $P$. xylostella resistant or susceptible to the protein Cry1Ac (Li et al., 2011; Tian et al., 2012; Liu et al., 2015). The predators O. insidiosus, Geocoris punctipes (Say) (Hemiptera: Geocoridae), Zelus renardii (Kolenati) (Hemiptera: Reduviidae) and Chrysoperla rufilabris (Steinmann) (Neuroptera: Chrysopidae) did not show a negative effect in their biology when feeding on caterpillars of T. ni resistant to the proteins Cry1 Ac and Cry2Ab and of $S$. frugiperda caterpillars resistant to Cry $1 F$ (Tian et al., 2013, 2014; Su et al., 2015). In the studies cited, susceptible prey were used, that showed evolution of resistance to the Cry proteins induced with the aim of evaluating the effects on the natural enemies. This information corroborated the results of the present study, indicating that prey resistant to the Cry proteins did not compromise the efficiency of the foraging of the predators $O$. insidiosus and $D$. luteipes.

The introduction of $D$. luteipes and $O$. insidiosus onto the corn plants, separately or together, reduced the injury scores from $S$. frugiperda caterpillars, since larval survival was greater where there were no predators. Both species presented the same predation behaviour, with the same efficiency of control in greenhouse, in contrast to that observed in bioassays in the laboratory. Therefore, the realization of experiments in semi-field greenhouse and field environments are fundamental to evaluate predation behaviour correctly. These results show a possible compatibility for the use of a number of predators, given that the injury scores were statistically similar (according to the interval of confidence of the bars) when used separately or together, and the larval survival also showed no difference.

For P. nigrispinus, the damage caused by susceptible $S$. frugiperda was evaluated using the injury score applying the scale of Carvalho (1970) on Bt and non-Bt plants, in the presence or absence of predators in a greenhouse. The Bt corn controlled the fall armyworm, and the introduction of P. nigrispinus significantly reduced the injury score up to the last day of evaluation (Leite et al., 2014). These results are similar to those of the present study, showing that the combined action of Bt corn and natural enemies can favour the control of the fall armyworm, reducing the damage caused even when there are populations of resistant caterpillars. Therefore, it is clear that the action of natural enemies can slow the evolution of resistance by Bt plant pests, given that even the minimal presence of predators (only one per plant) was able to generate efficient control of the fall armyworm resistant to the protein Cry1F.

The results of this study demonstrate that, when there is resistance in the fall armyworm to Bt proteins, the injury in transgenic plants is equivalent to that provoked in conventional corn, but the presence of the predators $O$. insidiosus and D. luteipes contributes to the control of the pest without affecting predation behaviour. Given that the predation capacity of these predators during the different developmental stages of $S$. frugiperda did not change as a function of the status of resistance to the Cry1F protein, we can infer that the predators do not perceive the presence of the protein in prey. This information can help in the combined application of resistant transgenic plants and biological control in the integrated management and resistance management of the fall armyworm in corn culture.

\section{Conclusions}

S. frugiperda resistant to the Cry1F protein did not alter the searching behaviour or predation capacity of $O$. insidiosus and D. luteipes.

The predation capacity of $O$. insidiosus and $D$. luteipes increased according to the predator's developmental stage, independent of the prey being resistant or susceptible.

The combination of Bt corn that expresses the Cry1F protein (event TC1507) with the predators $O$. insidiosus and $D$. luteipes reduces the injuries caused by $S$. frugiperda, even when the caterpillars are resistant to the transgenic event.

\section{Acknowledgements}

The authors thank the Programa de Pós-Graduação em Entomologia of UFLA, for the scientific support to the student. To Fapemig for granting the Phd scholarship to the first author. To Embrapa Maize and Sorghum for allowing this research to be carried out and we thank Eustáquio Francisco Souza de Oliveira for assisting with insect rearing.

\section{References}

ALBAJES, R., LÓPEZ, C. and PONS, X., 2003. Predatory fauna in corn fields and response to imidacloprid seed treatment. Journal of Economic Entomology, vol. 96, no. 6, pp. 1805-1813. http:// dx.doi.org/10.1093/jee/96.6.1805. PMid:14977119.

ARAÚJO, L.F., SILVA, A.G., CRUZ, I., CARMO, E.L., HORVATH NETO, A., GOULART, M.M.P. and RATTES, J.F., 2011. Flutuação populacional de Spodoptera frugiperda (J. E. SMITH), Diatraea saccharalis (FABRICIUS) e Doru luteipes (SCDDER) em milho convencional e transgênico Bt. Revista Brasileira de Milho e Sorgo, vol. 10, no. 3, pp. 205-214. http:// dx.doi.org/10.18512/1980-6477/rbms.v10n3p205-214.

BERNARDI, O., BERNARDI, D., RIBEIRO, R.S., OKUMA, D.M., SALMERON, E., FATORETTO, J., MEDEIROS, F.C.L., BURD, T. and OMOTO, C., 2015. Frequency of resistance to Vip3Aa20 toxin from Bacillus thuringiensis in Spodoptera frugiperda (Lepidoptera: Noctuidae) populations in Brazil. Crop Protection, vol. 76, pp. 7-14. http://dx.doi.org/10.1016/j. cropro.2015.06.006.

BOREGAS, K.G.B., MENDES, S.M., WAQUIL, J.M. and FERNANDES, G.W., 2013. Estádio de adaptação de Spodoptera frugiperda (J. E. Smith) (Lepidoptera: Noctuidae) em hospedeiros alternativos. Bragantia, vol. 72, no. 1, pp. 61-70. http://dx.doi. org/10.1590/S0006-87052013000100009.

BORTOLI, S.A.D., VACARI, A.M., LAURENTIS, V.L., BORTOLI, C.P.D., SANTOS, R.F. and OTUKA, A.K., 2016. Selection of prey to improve biological parameters of the predator Podisus nigrispinus (Dallas, 1851) (Hemiptera: Pentatomidae) in laboratory conditions. Brazilian Journal of Biology $=$ Revista Brasileira de Biologia, vol. 76, no. 2, pp. 307-314. http://dx.doi. org/10.1590/1519-6984.12914. PMid:26934159. 
BUENO, V.H.P., 2000. Desenvolvimento e multiplicação de percevejos predadores do gênero Orius Wolff. In: V.H.P. BUENO, ed. Controle biológico de pragas: produção massal e controle de qualidade. Lavras: Editora UFLA, pp. 69-90.

BUTLER, C.D. and O’Neil, R.J., 2006. Life history characteristics of Orius insidiosus (Say) fed diets of soybean aphid, Aphis glycines Matsumura and soybean thrips, Neohydatothrips variabilis (Beach). Biological Control, vol. 40, no. 3, pp. 339-346. http:// dx.doi.org/10.1016/j.biocontrol.2006.12.005.

CARVALHO, R.P.L., 1970. Danos, flutuação da população, controle e comportamento de Spodoptera frugiperda (J. E. Smith, 1797) e susceptibilidade de diferentes genótipos de milho, em condições de campo. Piracicaba: Escola Superior de Agricultura "Luiz de Queiróz", 170 p. Tese de Doutorado em Entomologia.

CHOW, A., CHAU, A. and HEINZ, K.M., 2010. Compatibility of Amblyseius (Typhlodromips) swirskii (Athias-Henriot) (Acari: Phytoseiidae) and Orius insidiosus (Hemiptera: Anthocoridae) for biological control of Frankliniella occidentalis (Thysanoptera: Thripidae) on roses. Biological Control, vol. 53, no. 2, pp. 188196. http://dx.doi.org/10.1016/j.biocontrol.2009.12.008.

COMISSÃO TÉCNICA NACIONAL DE BIOSSEGURANÇACTNBio, 2008 [viewed 20 October 2016]. Resolução normativa $n^{\circ}$ 6, de 6 de novembro de 2008 [online]. Diário Oficial da República Federativa do Brasil, Brasilia, 7 nov. Available from: http://ctnbio. mcti.gov.br/resolucoes-normativas/

COMISSÃO TÉCNICA NACIONAL DE BIOSSEGURANÇACTNBio, 2009 [viewed 20 October 2016]. Resolução normativa $n^{\circ} 8$, de 3 de junho de 2009 [online]. Diário Oficial da República Federativa do Brasil, Brasilia, 3 jun. Available from: http://ctnbio. mcti.gov.br/resolucoes-normativas/

CRUZ, I., 1995. A lagarta-do-cartucho na cultura do milho. Sete Lagoas: Embrapa Milho e Sorgo. 45 p. Circular Técnica, no. 21.

CRUZ, I., 2000. Métodos de criação de agentes entomófagos de Spodoptera frugiperda (J.E. Smith). In: V.H.P. BUENO, ed. Controle biológico de pragas: produção massal e controle de qualidade. Lavras: Editora UFLA, pp. 112-114.

CRUZ, I., 2007. Controle biológico de pragas na cultura de milho na produção de conservas (mini-milho), por meio de parasitoides e predadores. Sete Lagoas: Embrapa Milho e Sorgo, 16 p. Circular Técnica, no. 91.

CRUZ, I., ALVARENGA, C.D. and FIGUEIREDO, P.E.F., 1995 [viewed 20 October 2016]. Biologia de Doru luteipes (Scudder) e sua capacidade predatória de Helicoverpa zea (Boddie). Anais da Sociedade Entomológica do Brasil [online], vol. 24, no. 2, pp. 273-278. Available from: http://ainfo.cnptia.embrapa.br/digital/ bitstream/item/50800/1/Biologia-Doru-1.pdf

DOGRAMACI, M., ARTHURS, S.P., CHEN, J., MCKENZIE, C., IRRIZARY, F. and OSBORNE, L., 2011. Management of chilli thrips Scirtothrips dorsalis (Thysanoptera: Thripidae) on peppers by Amblyseius swirskii (Acari: Phytoseiidae) and Orius insidiosus (Hemiptera: Anthocoridae). Biological Control, vol. 59, no. 3, pp. 340-347. http://dx.doi.org/10.1016/j.biocontrol.2011.09.008.

FARIAS, J.R., ANDOW, D.A., HORIKOSHI, R.J., SORGATTO, R.J., FRESIA, P., SANTOS, A.C. and OMOTO, C., 2014. Fieldevolved resistance to Cry1F maize by Spodoptera frugiperda (Lepidoptera: Noctuidae) in Brazil. Crop Protection, vol. 64, pp. 150-158. http://dx.doi.org/10.1016/j.cropro.2014.06.019.

FIGUEIREDO, M.L.C., DIAS, A.M.P.M. and CRUZ, I., 2006. Associação entre inimigos naturais e Spodoptera frugiperda (j.e. smith, 1797) (lepidoptera: noctuidae) na cultura do milho. Revista Brasileira de Milho e Sorgo, vol. 5, no. 3, pp. 340-350. http:// dx.doi.org/10.18512/1980-6477/rbms.v5n3p340-350.

GOERGEN, G., KUMAR, P.L., SANKUNG, S.B., TOGOLA, A. and TAMO, M., 2016. First report of outbreaks of the fall armyworm Spodoptera frugiperda (J E Smith) (Lepidoptera, Noctuidae), a New Alien Invasive Pest in West and Central Africa. PLoS One, vol. 11, no. 10, pp. e0165632. http://dx.doi.org/10.1371/journal. pone.0165632. PMid:27788251.

HUANG, F., QURESHI, J.A., MEAGHER, R.L., REISIG, D.D., HEAD, G.P., ANDOW, D.A., NI, X., KERNS, D., BUNTIN, G.D., NIU, Y., YANG, F. and DANGAL, V., 2014. Cry1F resistance in fall armyworm Spodoptera frugiperda: single gene versus pyramided Bt maize. PLoS One, vol. 9, no. 11, pp. e112958. http://dx.doi.org/10.1371/journal.pone.0112958. PMid:25401494.

LAWO, N.C., WÄCKERS, F.L. and ROMEIS, J., 2010. Characterizing indirect prey-quality mediated effects of a Bt crop on predatory larvae of the green lacewing, Chrysoperla carnea. Journal of Insect Physiology, vol. 56, no. 11, pp. 1702-1710. http://dx.doi. org/10.1016/j.jinsphys.2010.06.012. PMid:20619267.

LEITE, N.A., MENDES, S.M., SANTOS, C.A. and PEREIRA, E.J.G., 2014. Does Cry1 Ab maize interfere in the biology and behavioural traits of Podisus nigrispinus? Bulletin of Insectology, vol. 67 , no. 2 , pp. $265-271$.

LEITE, N.A., MENDES, S.M., SANTOS-AMAYA, O.F., SANTOS, C.A., TEIXEIRA, T.P.M., GUEDES, R.N.C. and PEREIRA, E.J.G., 2016. Rapid selection and characterization of Cry1F resistance in Brazilian strain of fall armyworm. Entomologia Experimentalis et Applicata, vol. 158, no. 3, pp. 236-247. http:// dx.doi.org/10.1111/eea.12399.

LI, Y., ROMEIS, J., WANG, P., PENG, Y. and SHELTON, A.M., 2011. A comprehensive assessment of the Effects of Bt Cotton on Coleomegilla maculata demonstrates no detrimental effects by Cry1Ac and Cry2Ab. PLoS One, vol. 6, no. 7, pp. e22185. http://dx.doi.org/10.1371/journal.pone.0022185. PMid:21765949.

LIU, X., ABRO, G.H., HAN, F., TIAN, J., CHEN, M., ONSTAD, D., ROUSH, R., ZHANG, Q. and SHELTON, A.M., 2015. Effect of Bt broccoli and resistant genotype of Plutella xylostella (Lepidoptera: Plutellidae) on life history and prey acceptance of the predator Coleomegilla maculata (Coleoptera: Coccinellidae). Biological Control, vol. 91, pp. 55-61. http://dx.doi.org/10.1016/j. biocontrol.2015.07.010.

LIU, X., CHEN, M., COLLINS, H.L., ONSTAD, D.W., ROUSH, R.T., ZHANG, Q., EARLE, E.D. and SHELTON, A.M., 2014. Natural enemies delay insect resistance to Bt crops. PLoS One, vol. 9, no. 3, pp. e90366. http://dx.doi.org/10.1371/journal. pone.0090366. PMid:24595158.

LUNDGREN, J.G., GASSMANN, A.J., BERNAL, J., DUAN, J.J. and RUBERSON, J., 2009. Ecological compatibility of GM crops and biological control. Crop Protection, vol. 28, no. 12, pp. 1017-1030. http://dx.doi.org/10.1016/j.cropro.2009.06.001.

MENDES, S.M. and BUENO, V.H.P., 2001. Biologia de Orius insidiosus (Say) (Hemiptera: Anthocoridae) alimentado com Caliothrips phaseoli (Hood) (Thysanoptera: Thripidae). Neotropical Entomology, vol. 30, no. 3, pp. 423-428. http://dx.doi.org/10.1590/ S1519-566X2001000300014.

MENDES, S.M., BUENO, V.H.P., ARGOLO, V.M. and SILVEIRA, L.C.P., 2002. Type of prey influences biologyand consumption rate of Orius insidiosus (Say) (Hemiptera, Anthocoridae). Revista 
Brasileira de Entomologia, vol. 46, no. 1, pp. 99-103. http:// dx.doi.org/10.1590/S0085-56262002000100012.

MENDES, S.M., BUENO, V.H.P., CARVALHO, L.M. and SILVEIRA, L.C.P., 2003. Efeito da densidade de ninfas de Aphis gossypii Glover, 1877 (Hemiptera, Aphididae) no consumo alimentar e aspectos biológicos de Orius insidiosus (Say, 1832) (Hemiptera, Anthocoridae). Revista Brasileira de Entomologia, vol. 47, no. 1, pp. 19-24. http://dx.doi.org/10.1590/S0085-56262003000100004.

MENDES, S.M., BRASIL, K.G.B., WAQUIL, M.S., MARUCCI, R.C. and WAQUIL, J.M., 2012a. Biological and behavioral aspects of of predator, Orius insidiosus (SAY, 1832) in Bt and non-Bt maize. Bioscience Journal, vol. 28, no. 5, pp. 753-761.

MENDES, S.M., RESENDE, D.C., LEITE, N.A., OLIVEIRA, F.S., SANTOS, C.A. and BARBOSA, T.A.N., 2012b. Avaliação de variáveis comportamentais como metodologia para estudo de organismos não alvo em milho Bt. Sete Lagoas: EMBRAPA/ CNPMS, 7 p. Circular Técnica, no. 21.

MOSCARDINI, V.F., GONTIJO, P.C., CARVALHO, G.A., OLIVEIRA, R.L., MAIA, J.B. and SILVA, F.F., 2013. Toxicity and sublethal effects of seven insecticides to eggs of the flower bug Orius insidiosus (Say) (Hemiptera: anthocoridae). Chemosphere, vol. 92, no. 5, pp. 490-496. http://dx.doi.org/10.1016/j. chemosphere.2013.01.111. PMid:23481303.

NARANJO, S.E., 2009. Impacts of Bt crops on non-target invertebrates and insecticide use patterns. Perspectives in Agriculture, Veterinary Science, Nutrition and Natural Resources, vol. 4, no. 4, pp. 1-11. http://dx.doi.org/10.1079/PAVSNNR20094011.

OLIVEIRA, J.E.M., BORTOLI, S.A., SANTOS, R.F. and SILVEIRA, L.C.P., 2008. Efeito de cultivares de algodoeiro sobre a biologia e capacidade predatória de Orius insidiosus (Say, 1832) (Hemiptera: Anthocoridae) Predando Aphis gossypii Glover, 1877 (Hemiptera: Aphididae). Arquivos do Instituto Biológico, vol. 75 , no. 1, pp. 45-52.

PARRA, J.R.P., 1996. Técnicas de criação de insetos para programas de controle biológico. 3. ed. Piracicaba: FEALQ, 137 p.

PASINI, A., PARRA, J.R.P. and LOPES, J.M., 2007. Dieta artificial para criação de Doru luteipes (Scudder) (Dermaptera: Forficulidae), predador da lagarta-do-cartucho do milho Spodoptera frugiperda (J.E. Smith) (Lepidoptera: Noctuidae). Neotropical Entomology, vol.36, no. 2, pp. 308-311. http://dx.doi.org/10.1590/ S1519-566X2007000200020. PMid:17607467.

PAULA, D.P., ANDOW, D.A., BELLINATI, A., TIMBÓ, R.V., SOUZA, L.M., PIRES, C.S.S. and SUJII, E.R., 2016. Limitations in dose-response and surrogate species methodologies for risk assessment of Cry toxins on arthropod natural enemies. Ecotoxicology, vol. 25 , no. 3, pp. 601-607. http://dx.doi.org/10.1007/s10646016-1619-9. PMid:26846212.

PERDIKIS, D., FANTINOU, A. and LYKOURESSIS, D., 2011. Enhancing pest control in annual crops by conservation of predatory Heteroptera. Biological Control, vol. 59, no. 1, pp. 13-21. http:// dx.doi.org/10.1016/j.biocontrol.2011.03.014.

REIS, L.L., OLIVEIRA, L.J. and CRUZ, I., 1988. Biologia e potencial de Doru luteipes no controle de Spodoptera frugiperda. Pesquisa Agropecuária Brasileira, vol. 23, no. 4, pp. 333-342.

RITCHIE, S.W., HANWAY, J.J. and BENSON, G.O., 1986. How a corn plant develops. Iowa: State University of Science and Technology Cooperative Extension Service Ames, 24 p.

ROMEIS, J., BARTSCH, D., BIGLER, F., CANDOLFI, M.P., GIELKENS, M.M.C., HARTLEY, S.E., HELLMICH, R.,
HUESING, J.E., JEPSON, P.C., LAYTON, R., QUEMADA, H., RAYBOULD, A., ROSE, R.I., SCHIEMANN, J., SEARS, M.K., SHELTON, A.M., SWEET, J., VAITUZIS, Z. and WOLT, J.D., 2008. Assesment of risk of insect-resistant transgenic crops to non-target arthropods. Nature Biotechnology, vol. 26, no. 2, pp. 203-208. http://dx.doi.org/10.1038/nbt1381. PMid:18259178.

ROMEIS, J., HELLMICH, R.L., CANDOLFI, M.P., CARSTENS, K., SCHRIJVER, A., GATEHOUSE, A.M.R., HERMAN, R.A., HUESING, J.E., MCLEAN, M.A., RAYBOULD, A., SHELTON, A.M. and WAGGONER, A., 2011. Recommendations for the design of laboratory studies on non-target arthropods for risk assessment of genetically engineered plants. Transgenic Research, vol. 20 , no. 1, pp. 1-22. http://dx.doi.org/10.1007/s11248-0109446-x. PMid:20938806.

ROMEIS, J., MEISSLE, M. and BIGLER, F., 2006. Transgenic crops expressing Bacillus thuringiensis toxins and biological control. Nature Biotechnology, vol. 24, no. 1, pp. 63-71. http:// dx.doi.org/10.1038/nbt1180. PMid:16404399.

ROMEIS, J., RAYBOULD, A., BIGLER, F., CANDOLFI, M.P., HELLMICH, R.L., HUESING, J.E. and SHELTON, A.M., 2013. Deriving criteria to select arthropod species for laboratory tests to assess the ecological risks from cultivating arthropod-resistant genetically engineered crops. Chemosphere, vol. 90, no. 3, pp. 901-909. http://dx.doi.org/10.1016/j.chemosphere.2012.09.035. PMid:23062830.

SCHRIJVER, A.D., DEVOS, Y., CLERCQ, P., GATHMANN, A. and ROMEIS, J., 2016. Quality of laboratory studies assessing effects of Bt-proteins on non-target organisms: minimal criteria for acceptability. Transgenic Research, vol. 25, no. 4, pp. 395-411. http://dx.doi.org/10.1007/s11248-016-9950-8. PMid:26980555.

SHELTON, A.M., ROMEIS, J., NARANJO, S.E., TIAN, J. and HELLMICH, R.L., 2016. Use of Bt-resistant caterpillars to assess the effect of Cry proteins on beneficial natural enemies. GMOs in Integrated Plant Production, vol. 114, pp. 51-55.

SILVEIRA, L.C.P., BUENO, V.H.P. and VAN LENTEREN, J.C., 2004. Orius insidiosus as biological control agent of thrips in greenhouse chrysanthemums in the tropics. Bulletin of Insectology, vol. 57 , no. 2 , pp. 103-109.

SOUSA, F.F., MENDES, S.M., SANTOS-AMAYA, O.F., ARAÚJO, O.G., OLIVEIRA, E.E. and PEREIRA, E.J.G., 2016. Life-history traits of Spodoptera frugiperda populations exposed to low-dose Bt maize. PLoS One, vol. 11, no. 5, pp. e0156608. http://dx.doi. org/10.1371/journal.pone.0156608. PMid:27243977.

SOUZA, C.S.F., SILVEIRA, L.C.P., PAULA, D.P., ANDOW, D.A. and MENDES, S.M., 2018. Transfer of Cry1F from Bt maize to eggs of resistant Spodoptera frugiperda. PLoS One, vol. 13, no. 9, pp. e0203791. http://dx.doi.org/10.1371/journal. pone.0203791. PMid:30208091.

STORER, N.P., BABCOCK, J.M., SCHLENZ, M., MEADE, T., THOMPSON, G.D., BING, J.W. and HUCKABA, R.M., 2010. Discovery and characterization of field resistance to Bt maize: Spodoptera frugiperda (Lepidoptera: Noctuidae) in Puerto Rico. Journal of Economic Entomology, vol. 103, no. 4, pp. 1031-1038. http://dx.doi.org/10.1603/EC10040. PMid:20857709.

STORER, N.P., KUBISZAKET, M.E., KING, J.E., THOMPSON, G.D. and SANTOS, A.C., 2012. Status of resistance to Bt maize in Spodoptera frugiperda: lessons from Puerto Rico. Journal of Invertebrate Pathology, vol. 110, no. 3, pp. 294-300. http://dx.doi. org/10.1016/j.jip.2012.04.007. PMid:22537834 
SU, H.H., TIAN, J.C., NARANJO, S.E., ROMEIS, J., HELLMICH, R.L. and SHELTON, A.M., 2015. Bacillus thuringiensis plants expressing Cry1 Ac, Cry2 Ab and Cry1F are not toxic to the assassin bug, Zelus renardii. Journal of Applied Entomology, vol. 139, no. 1-2, pp. 23-30. http://dx.doi. org/10.1111/jen.12184.

TIAN, J.C., COLLINS, H.L., ROMEIS, J., NARANJO, S.E., HELLMICH, R.L. and SHELTON, A.M., 2012. Using field-evolved resistance to Cry1F maize in a lepidopteran pest to demonstrate no adverse effects of Cry1F on one of its major predators. Transgenic Research, vol. 21, no. 6, pp. 1303-1310. http://dx.doi.org/10.1007/s11248-012-9604-4. PMid:22373893.

TIAN, J.C., LONG, L.P., WANG, X.P., NARANJO, S.E., ROMEIS, J., HELLMICH, R.L., WANG, P. and SHELTON, A.M., 2014. Using resistant prey demonstrates that Bt plants producing Cry $1 \mathrm{Ac}$, Cry2 Ab, and Cry $1 \mathrm{~F}$ have no negative effects on Geocoris punctipes and Orius insidiosus. Environmental Entomology, vol. 43, no. 1, pp. 242-251. http://dx.doi.org/10.1603/ EN13184. PMid:24472212.

TIAN, J.C., WANG, X.P., LONG, L.P., ROMEIS, J., NARANJO, S.E., HELLMICH, R.L., WANG, P., EARLE, E.D. and SHELTON, A.M., 2013. Bt crops producing Cry1Ac, Cry2Ab and Cry1F do not harm the green lacewing, Chrysoperla rufilabris. PLoS
One, vol. 8, no. 3, pp. e60125. http://dx.doi.org/10.1371/journal. pone.0060125. PMid:23544126.

TIAN, J.C., YAO, J., LONG, L.P., ROMEIS, J. and SHELTON, A.M., 2015. Bt crops benefit natural enemies to control nontarget pests. Scientific Reports, vol. 5, pp. 16636. http://dx.doi. org/10.1038/srep16636. PMid:26559133.

VAN LENTEREN, J.C., 2012. The state of commercial augmentative biological control: plenty of natural enemies, but a frustrating lack of uptake. BioControl, vol. 57, no. 1, pp. 1-20. http://dx.doi. org/10.1007/s10526-011-9395-1.

VAN LENTEREN, J.C., BOLCKMANS, K., KÖHL, J., RAVENSBERG, W.J. and URBANEJA, A., 2018. Biological control using invertebrates and microorganisms: plenty of new opportunities. BioControl, vol. 63, no. 1, pp. 39-59. http://dx.doi. org/10.1007/s10526-017-9801-4.

WONG, S.K. and FRANK, S.D., 2013. Pollen increases fitness and abundance of Orius insidiosus Say (Heteroptera: Anthocoridae) on banker plants. Biological Control, vol. 64, no. 1, pp. 45-50. http://dx.doi.org/10.1016/j.biocontrol.2012.09.015.

YOO, H.J.S. and O’Neil, R., 2009. Temporal relationships between the generalist predator, Orius insidiosus, and its two major prey in soybean. Biological Control, vol. 48, no. 2, pp. 168-180. http:// dx.doi.org/10.1016/j.biocontrol.2008.10.007. 